may draw an analogy from the moon. The real existence of a term with coefficient nearly three seconds and period sixty-four years is now generally admitted in the motion of the moon. This term was first defined in I904, and the case for its real existence was not a strong one until Prof. Newcomb arrived in. 1909 at an almost identical conclusion from the totally different evidence of occultations. The term in the motion of Uranus must therefore be doubtful for the present. We are not entitled to do more at present than hope that it is real, and that a corresponding planet will reward M. Gaillot's admirable work. This doubt is fully admitted by M. Gaillot.

"Ces résultats ne doivent être acceptés d'ailleurs qu'avec une extrême réserve. En effet, les différences entre les positions observées d'Uranus et celles qui sont calculées a l'aide de nos Tables ne dépassent guère les limites des erreurs probables des observations augmentées de celles qui résultent des imperfections de la théorie. ..."

It is noteworthy that, like Prof. Pickering, M. Gaillot bases his hypothetical planet upon Uranus and not upon Neptune. It appears, therefore, that the motion of Neptune is in good agreement with the tables, and that no extra-Neptunian planet can exist of a mass and epoch to produce sensible inequalities in the motion of Neptune since its discovery. This is an important negative result; in fact, if it be assumed that the unknown planet has a mass at least one-third that of Neptune, a considerable part of the ecliptic is excluded from the domain where this planet can possibly be found.

\section{THE SORBY RESEARCH FELLOWSHIP.}

$\mathrm{T}_{\mathrm{T}}$ will be remembered that the late Dr. H. C. Sorby, 1 F.R.S., of Sheffield, bequeathed a sum of ${ }_{5}, 000 l$. to the Royal Society of London to be held in trust for the establishment of a professorship or fellowship for original scientific research, the testator expressly desiring the professorship or fellowship thus founded to be associated with the University of Sheffield. Accepting this trust, the council of the Royal Society appointed a committee to confer with representatives of the University of Sheffield with the view of drawing up a scheme for giving effect to the intentions of Dr. Sorby's will.

A scheme, prepared by this committee for the establishment of a "Sorby Fellowship for Scientific Research" to be associated with the University of Sheffield, has now been approved and adopted by the council of the Royal Society, and by the senate and council of the University of Sheffield. This scheme provides for the administration of the income of the fund by a joint committee consisting of four persons appointed by the council of the Royal Society, one person appointed by the council of the University of Sheffield, and two by the senate of that University.

The object of the fellowship is not to train students for original research, but to obtain advances in natural knowledge by enabling men of proved ability to devote themselves to research; and in making an appointment the committee will pay special attention to the capacity for original work of a candidate, as shown by the work already done by him, and to the likelihood that he will continue to do valuable work. Each appointment will be in the first instance for five years, subject to the control of the committee, but may in special circumstances be prolonged for further periods if the committee is satisfied with the fellow's work.

The fellow will be required to carry out his research, when possible, in one of the laboratories of the University of Sheffield, and provision is made under the regulations for the setting aside of a sum not exceeding $50 l$. a year to form an apparatus fund, from which grants may be made from time to time to the fellow for the purchase of special apparatus and material required in his research. The stipend of the Sorby Research Fellow will probably be about $500 l$. per annum, and it is hoped that the committee will be in a position to make the first appointment to the fellowship early in the coming autumn.

\section{PROF. T. W. BRIDGE, F.R.S.}

$W^{E}$ regret to record the death, on June 30 , of $\mathrm{Dr}$. T. W. Bridge, Mason professor of zoology in the University of Birmingham. By his death the University is deprived of one of its oldest and most experienced teachers, and zoological science has lost one of those workers who, under the influence of Balfour and the Cambridge school, have contributed largely both by example and precept to our knowledge of vertebrate morphology.

Prof. Bridge was born in Birmingham in 1848 , and after studying science at the Birmingham and Midland Institute, went in 1870 to Cambridge as assistant to Mr. J. W. Clark, then director of the Museum of Zoology. In $187^{2}$ he was elected to a foundation scholarship at Trinity College, and appointed demonstrator in zoology under the late Prof. Newton. After his graduation in 1875 , he spent six months at Naples working in the zoological station, where, on the advice of F. M. Balfour, he carried out research into the "abdominal pores" of fishes. In 1879 he was appointed professor of zoology in the Royal College of Science at Dublin. In 1880 he became one of the original professors at the Mason College, Birmingham, holding the chair of biology; and when this chair was divided in 1882 he retained the title of Mason professor of zoology and comparative anatomy, and kept the same position when the Mason College became a University in 1900 .

The original work carried out by Prof. Bridge dealt chiefly with the osteology of ganoid fish, the " poriabdominales" of vertebrates, and the air-bladder of Teleosts. The most important of these memoirs are undoubtedly those dealing with the last subject, and the large paper by Profs. Bridge and Haddon, published in the Philosophical Transactions in 1893 , on the air-bladder of Siluroids, has become a classic. This work was the first thorough investigation dealing with the structure and physiology of this organ which had appeared since Weber's original discovery and fundamental treatise on the air-bladder published in 1820 . In certain Siluroids, Weber found that extraordinary apparatus which still bears his name. He described in a few families the vertebral elements that link the air-bladder with the ear, and concluded that the apparatus subserved the function of hearing in these fish. What was now required was a systematic inquiry into the variation of this mechanism and into the use or uses of it; and it is this monographic treatment that we owe to Prof. Bridge and his collaborator. They investigated roo species of Siluroids, and concluded that this highly specialised mechanism was employed, not for audition, but for the registration of varying hydrostatic pressures. These memoirs not only advanced our knowledge of this interesting structure, but threw light on many points of ecological interest in connection with other physostomatous Teleosts.

Prof. Bridge's most recent work was his article on fishes in the "Cambridge Natural History." (I904). This article has proved one of the most useful treatises on this subject both to teachers and students. The

NO. $207 \mathrm{I}$, VOL. 8I] 
velue of his work was recognised by his election into the Royal Society in I903.

We must not conclude this short article without bearing witness to the great success of Prof. Bridge as a teacher. He excelled, to no common degree, in grounding his pupils in the elements of zoology. As examination candidates his students showed unusual accuracy, and, in the main, a wide knowledge. Those of them who were able to go further and undertake some piece of research found in him not only a stimulus, but an unwearied guide and a sagacious critic.

\section{NOTES.}

M. G. Darboux has been re-elected president of the Société des Amis des Sciences, MM. Aucoc and Picard vicepresidents, and Prof. Joubin general secretary. The society was founded in 1857 by Baron Thenard with the view of assisting unfortunate inventors, men of science, and professors and their families. Among the names of pastpresidents of the society occur those of Thenard, J. B. Dumas, Pasteur, and others. Since its foundation the society has distributed in pensions and grants more than two and a half million francs. This year eighty pensions have been granted to old savants or their widows. The society has assisted the education of some seventy children, and made grants to thirty-five widows. The work of the society should appeal to all who benefit from the work of men of science. Information as to the society may be obtained from the treasurer, M. Fouret, 79 boulevard Saint-Germain, Paris.

We learn from Science that the people of Honolulu have guaranteed already half the money asked for by the Massachusetts Institute of Technology for the maintenance of an observatory which the institute proposes to establish at the brink of Kilauea for the study of volcanic action.

THE Geologists' Association is arranging a long excursion to the Arenigs, from July 28 to August 7 , under the direction of Mr. W. G. Fearnsides. The excursion secretary is Mr. E. Montag, 4 Queen's Road, Rockferry, Birkenhead.

THE Vienna correspondent of the Times announces that during excavations near Willendorf on the Danube by the prehistoric section of the Austrian Natural History Museum, a chalk figurine, in centimetres high, representing a female figure, was discovered in a stratum containing instruments and weapons characteristic of the Stone age.

THE maps of the cadastral survey of Egypt have just been used to determine accurately the area of land planted with cotton and its distribution. Each plot in which cotton was sown was marked on the maps (scale $1 / 2500$ ), so that not only the area and position were recorded, but, since the land-tax has been recently re-assessed with the aid of these maps, the distribution of cotton on land of different degrees of fertility was also determined. The total area was $1,466,530$ feddans, or $1,522,258$ acres.

THE Naples Academy of Sciences (mathematical and physical section) offers a prize of 1000 lire for the best essay containing a systematic exposition of our present knowledge of the geometrical configurations of the plane and of spaces, considered in relation to the theory of substitutions, with, if possible, some new results. The memoirs are to be sent in anonymously not later than June 30, r. 9 10.

$$
\text { NO. } 207 \text { I, VOL. 8I] }
$$

In Travel and Exploration for July Mr. H. Massac Buist discusses what the nations are doing in the progress of aviation, and refers to the annual prize offered by him to the Aërial League for the best essay by a member of that body dealing with the attention that is being devoted by the leading civilised nations to the advancement of aërial locomotion. The first competition is to close on January 3I, I9I0. In his article the author shows that while Governments are mainly devoting their attention to the construction of dirigibles, aëroplane machines are, to a large extent, being developed by private enterprise.

WrItING in the Oxford and Cambridge Review, with a foreword by Lord Montagu of Beaulieu, Mr. R. P. Hearne advocates the introduction of aviation as a form of sport at the older universities. It is pointed out that such a scheme would produce a school of skilled aviators whose experience would be of great value in future developments of aërial navigation. While the possibility of an Oxford and Cambridge flying race is suggested, we would point out that, in view of the fact that the great majority of Varsity men cannot afford to spend roool. on a motordriven machine, the man of moderate means might participate in the sport by gliding down a suitable incline selected on the Gogmagogs, Madingley Hill, or Royston Heath.

THe number of records of earthquakes obtained at Shide, Göttingen, Hamburg, and Laibach between January $I$ and April 30 this year were, respectively, $98,65,61$, and 33 . Each of these earthquakes extended over wide areas, and was recorded at more than one station. At Shide the instrument employed is of the type adopted by the British Association. At the other stations the records were made on smoked paper or by photographic arrangements with a high multiplication.

ThE annual general meeting of the Royal Society of Arts, the $155^{\text {th }}$ since the foundation of the society in 1754 , was held on Wednesday, June $3^{\circ}$, Sir William H. White, K.C.B., chairman of the council, in the chair. The Prince of Wales was re-elected for the ninth time in succession president of the society, and the council, with certain additions and alterations, was re-elected. The principal business of the meeting was the reading of the annual report, which recorded the proceedings of the society during the past year. Reference was made to the failure of the renewed attempt made by the managers of the London Institution to amalgamate with the society. The number of the society's members is now 3490 .

THE Times announces that in July of next year there will be held in Brussels, in connection with the International Exhibition of I9Io, the first International Congress of Administrative Sciences, under the direct patronage of the Belgian Government. The term " administrative sciences" is defined by the congress committee as meaning the sum of theoretical knowledge relating to the services, the organisation, the machinery, and the action of Governments, and to the most practical methods to be employed by them. The honorary secretary to the British committee of the congress is Mr. G. Montagu Harris, Caxton House, Westminster, S.W.

TuE recent notices issued by the committee of the International Aëronautical Exhibition at Frankfort show that many valuable prizes, in addition to those we have already mentioned, have been placed at its disposal, including one by the German Emperor; three prizes are also offered for the best kinematographic films of natural flight. A series of scientific lectures will be delivered, the first being 